\title{
Some Morphological and Pigmental Characteristics in Rhododendron kaempferi Planch., R. kiusianum Makino and $R$. eriocarpum Nakai in Southern Kyushu
}

\author{
Yusuke Sakata ${ }^{1}$, Ken-ichi Arisumi ${ }^{1}$ and Ikuo Miyajima ${ }^{2}$ \\ ${ }^{1}$ Faculty of Agriculture, Kagoshima University, Kagoshima 890 \\ ${ }^{2}$ Faculty of Agriculture, Kyushu University, Fukuoka 812
}

\begin{abstract}
Summary
The variations in some morphological characteristics along with the pigmental ones of Rhododendron kaempferi Planch., $R$. kiusianum Makino and $R$. eriocarpum Nakai distributing in southern Kyushu, were investigated.

The populations of $R$. kaempferi in southern Kyushu showed much wider variations in flower-colour, flower-size and the occurrence of petal-blotch than those in northern Kyushu. Furthermore, in the former populations, anthocyanins of the delphinidin-series co-existed with the commonly occurring cyanidin-series, as compared with the latter whose anthocyanins were confined to the cyanidin-series. Hence, the southern populations of $R$. kaempferi seemed to have been resulted from the introgressions of other azaleas with anthocyanins of the delphinidin-series to the true forms.

Extremely narrow variations in the morphological and pigmental characteristics were shown in $R$. kiusianum, suggesting that populations distributing at and around the summit of volcanic mountain, Mt. Karakunidake, represent true species. On the other hand, population of $R$. eriocarpum at the summit of Mt. Kaimondake showed wider variations in flower-colour and the occurrence of flavonoid pigments than that of Mt. Ontake in Tokara-Archipelago. These variations seen in the former might be the result of the introgression of $R$. kaempferi occurring near the habitat of $R$. eriocarpum at the summit of Mt. Kaimondake.

In any case, the populations of $R$. kaempferi and $R$. eriocarpum in southem Kyushu exhibited wider variations and contained many peculiar individuals with respect to their floral characteristics. Therefore, we can easily adopt the more promising germplasms as the materials of future breeding among their natural variations.
\end{abstract}

\section{Introduction}

Japan is well known as a treasure house of the wild evergreen azaleas. Especially in Kyushu, wild evergreen azaleas classified as the series Kaempferia or allied series such as Indica and Macrosepara (7), occur widely and abundantly (8). Of these azaleas, $R$. kiusianum Makino, one of the most valuable species for ornamental use, distributes in the regions confined to the summits of high volcanic mountains, and $R$. kaempferi Planch., the

Received for publication 12 October 1990. Studies on the variations of characteristics in the evergreen azaleas. I. This work was supported by a grant from the Ministry of Education (No.60560038). most commonly occurring azalea in our country, is found at the foot of these mountains and along the west coast of Kyushu. Furthermore, $R$. eriocarpum Nakai, the flower-colour of this azalea has exerted great influences on the purplish tone of Satsuki azalea (4), distributes at the summits of the mountains in Tokara-Archipelago and the most southern part of Satsuma-Peninsula.

Since 1981, the authors have investigated the geographical distribution of the wild evergreen azaleas in Kyushu, in connection with their morphological and pigmental characteristics, especially in southern Kyushu where they exhibit great variation (2).

The present investigation was conducted to ob- 
tain detailed figures concerning the variations in flower-colour, flower-size, the occurrence-manner of petal-blotch and flavonoid pigments of $R$. kaempferi, $R$. kiusianum and $R$. eriocarpum, in southern Kyushu. The results dealing with other azaleas occurring on the Kirishima and Takakuma mountain masses which were regarded as the result of natural hybridization between wild species, will be presented in a forthcoming paper.

\section{Materials and Methods}

\section{Plant materials}

The localities where the flowers of evergreen azaleas were collected and investigated are shown in Fig. 1. The materials used were $R$. kaempferi from Satsuma-Peninsula (alt. $100 \sim 150 \mathrm{~m}$ ) and Ohsumi-Peninsula (alt. $50 \mathrm{~m}$ ), R. kiusianum from Ebino-Plateau (alt. 1,100 m) and the summit of Mt. Karakunidake (alt. $1,700 \mathrm{~m}$ ) and $R$. eriocarpum from the summits of Mt. Ontake (alt. $978 \mathrm{~m}$ ) in Nakano-Shima and Mt. Kaimondake (alt. $922 \mathrm{~m}$ ). In addition to these, $R$. kaempferi from Misumi Town (alt. $50 \mathrm{~m}$ ) and Kikuchi City (alt. $150 \sim 200 \mathrm{~m}$ ) were used in order to compare these two populations with those in southern Kyushu.

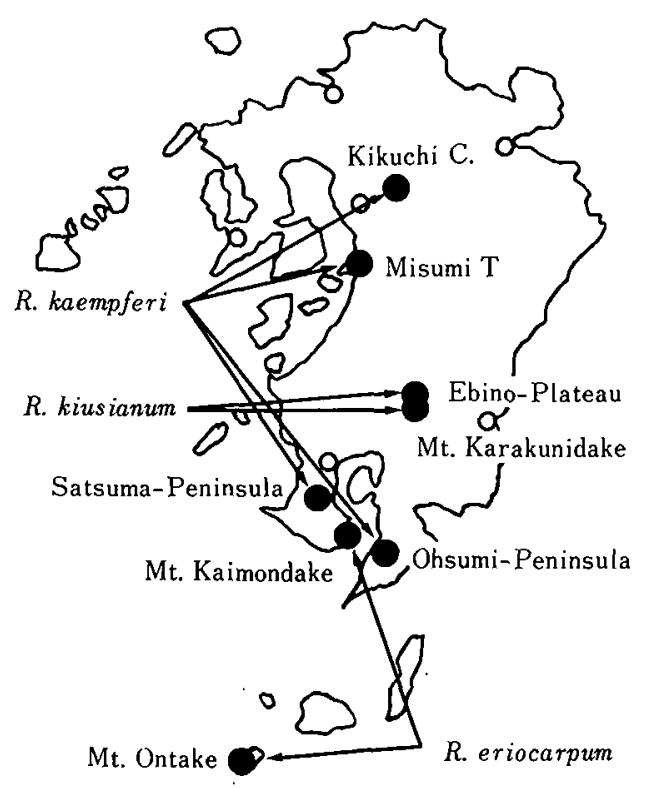

Fig. 1. Localities where the flowers of R. kaempferi, $R$. kiusianum and $R$. eriocarpum were investigated in Kyushu.
The number of individuals investigated for the phenotypic characteristics of petals was approximately 500 to 1,000 in each locality except for $R$. kaempferi from Misumi Town and Kikuchi City and $R$. eriocarpum from Mt. Kaimondake where nearly 100 individuals were sampled. For the pigmental characteristics of petals approximately 50 to 100 individuals were analyzed in each locality.

\section{Investigation of phenotypic characteristics of petals}

The colour of the flowers was recorded using the Royal Horticultural Society Colour Chart (RHSCC) and then, flower-diameter (mm) was measured followed by the assortment of flowers into three types according to the intensity of petalblotch; prominent, slight or none.

\section{Qualification and quantification of petal anthocya- nins and flavonols}

The detailed procedures used for pigmentextraction are shown in Fig. 2. Based on this method, no more than $10 \mathrm{mg}$ of dried petal was needed for analysis. Using a system of the high performance liquid chromatography (HPLC), pigment-eluates were separated into the respective pigment-fractions, then they were identified by a

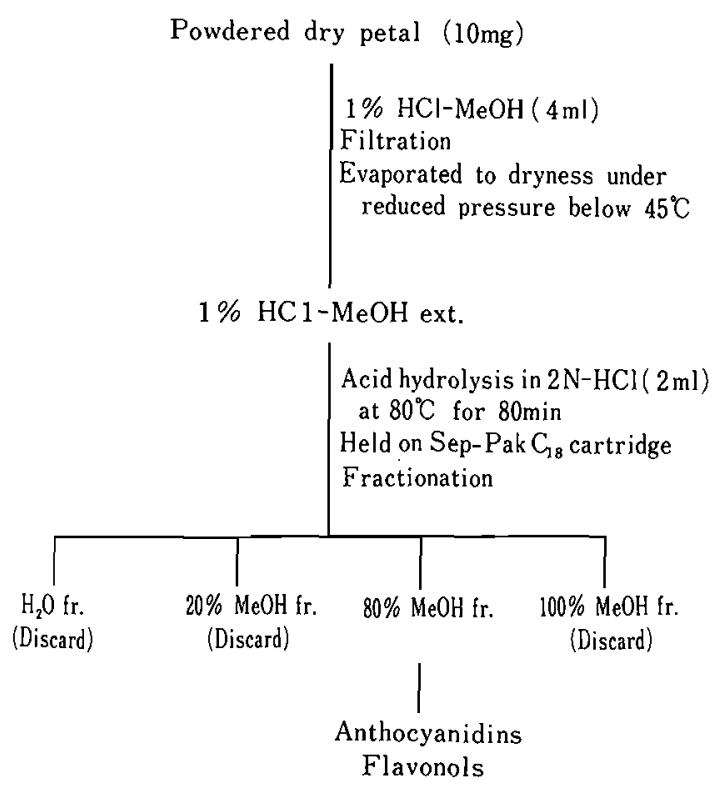

Fig. 2. Procedures for the extraction of pigments. 
comparison with authentic specimens. The ratio of the amount of each pigment to the total amount was also estimated. The analytical conditions of an HPLC were as follows: Chromatograms were run on a CCPD-8000 HPLC-system (TOSHO) using a $4.6 \mathrm{~mm}$ (I.D.) $\times 25 \mathrm{~cm}$ column packed with Nucleosil $7 \mathrm{C}_{18}$ (Macherey-Nagel) and a UV-8000 detector (TOSHO) set at $535 \mathrm{~nm}$ for anthocyanidins or $365 \mathrm{~nm}$ for flavonols. A flow-rate of $1.2 \mathrm{ml} / \mathrm{min}$ was maintained employing $50 \%$ $\mathrm{MeOH}$ containing $0.1 \% \mathrm{HClO}_{4}$ as an eluent.

\section{Results and Discussion}

Concerning flower-colour, the frequency distribution of individuals in the population of $R$. kaempferi based on the RHSCC presented in Fig. 3, showed that the variation found in the two southern populations (Satsuma- and OhsumiPeninsula) was somewhat wider than that found in the more northern ones (Misumi $T$. and Kikuchi
C). The former contained individuals with flowercolour ranging from vermillion through red to pink, whereas in the latter, the flowers were mainly red. Analogous situations to the above could be seen concerning flower-size and the presence of prominent blotches. Southern populations showed a much wider variation in flower-size, ranging from 26 to $60 \mathrm{~mm}$ in diameter, and contained nearly $10 \%$ of individuals with slight petal-blotch or without petal-blotch (Fig. 4).

As regards the petal-pigmentation, all individuals of all populations of $R$. kaempferi were flavonol free, and accordingly it was impossible for them to have contained 5-methylated flavonols (Fig. 5). On the other hand, as seen in Fig. 6, in petals of the two southern populations with RHSCC numbers above 49 , anthocyanins of the delphinidin-series, the most important constituents modifying the flower-colour to a much bluer tone, co-existed with the cyanidin-series commonly found in $R$. kaempferi
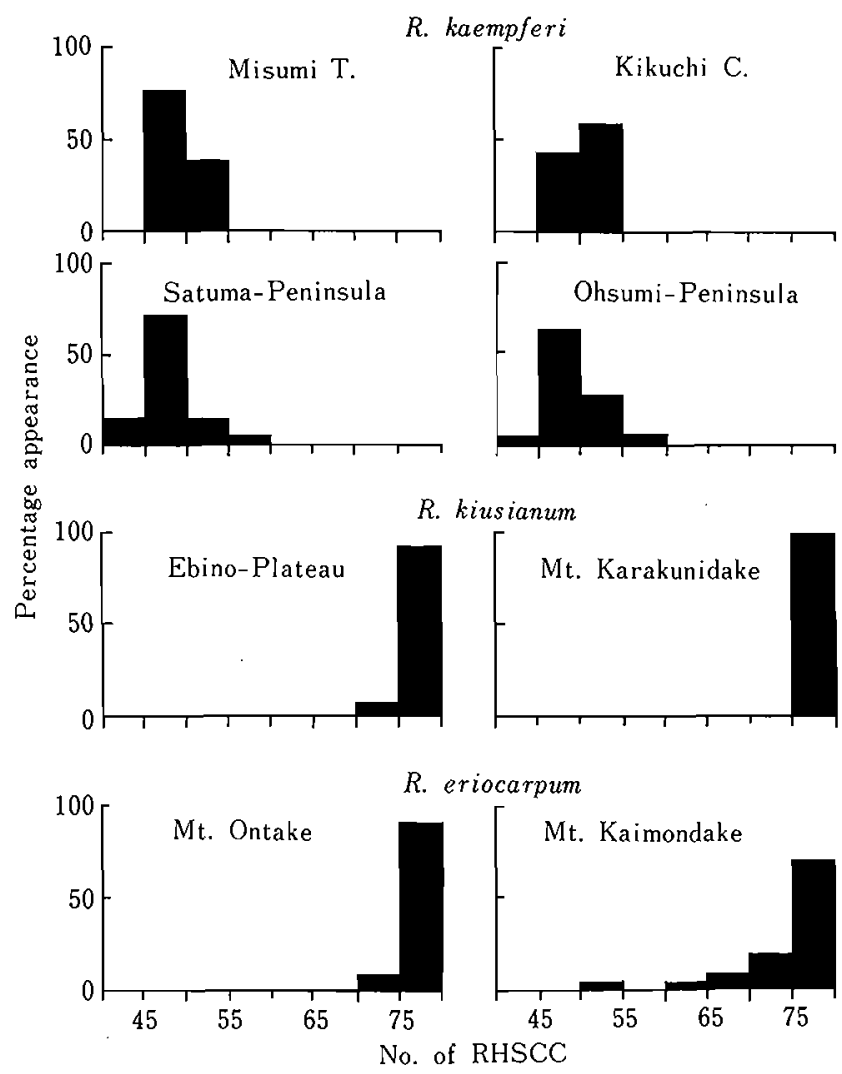

Fig. 3. Frequency distribution of individuals concerning flower-colour in $R$. kaempferi, $R$. kiusianum and $R$. eriocarpum. 


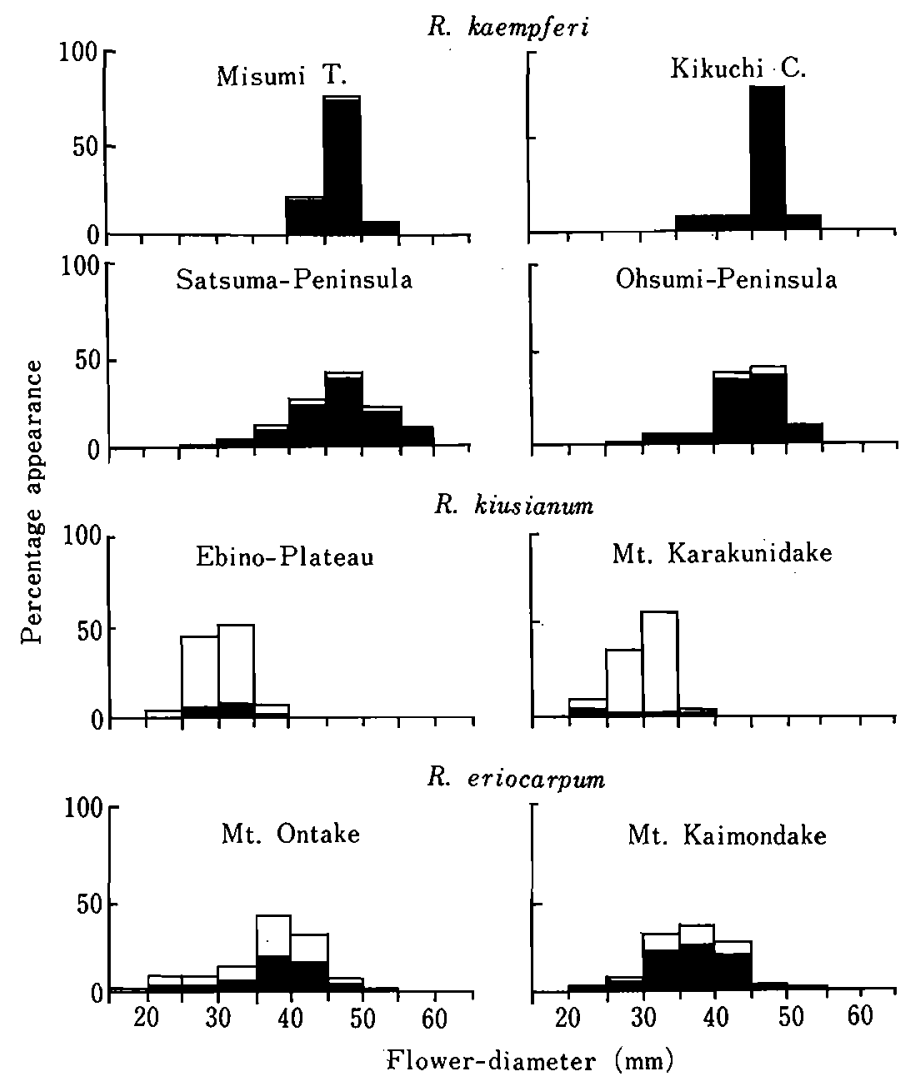

Fig. 4. Frequency distribution of individuals concerning flower-size and petalblotch in $R$. kaempferi, $R$. kiusianum and $R$. eriocarpum. Open column, flowers with slight blotches or without blotches; filled column, flowers with prominent blotches.

and other azaleas $(3,5,9)$. This may be one of the reasons why these southern populations showed a wider variation in flower-colour.

In general, the variation in morphological and pigmental characteristics in $R$. kaempferi is believed to be quite narrow, flower-colour being confined to vermilion or red, the flowers ranging in diameter from 40 to $50 \mathrm{~mm}$ with a prominent blotch (6), and having anthocyanins of the cyanidinseries alone and no flavonols. If we consider the typical $R$. kaempferi in Kyushu in the light of these concepts, populations in the northern localities which show such a narrow range of variation probably represent the true forms. On the other hand, populations in the southern Kyushu showing a wider range of variation might be the result of further introgressions of $R$. kaempferi, to the original hybrid population derived from the cross between R. kaempferi and other species with anthocyanins of the delphinidin-series (5).

$R$. kiusianum showed extremely narrow variation in flower-colour. More than $90 \%$ of the individuals of both populations showed RHSCC numbers above 75, purple or violet shade (Fig. 3). This situation was also supported by their pigmental characteristics. In all individuals of both populations, 40 to $75 \%$ of the total anthocyanins were of the highly hydroxylated delphinidin-series, and 5-methylated flavonols made up $40 \%$ to nearly $90 \%$ of the total flavonols (Figs. 5 and 6). The occurrence of the latter pigments is also thought to be a factor contributing to the bluer tone of the flower (1).

Concerning flower-size and the presence of 


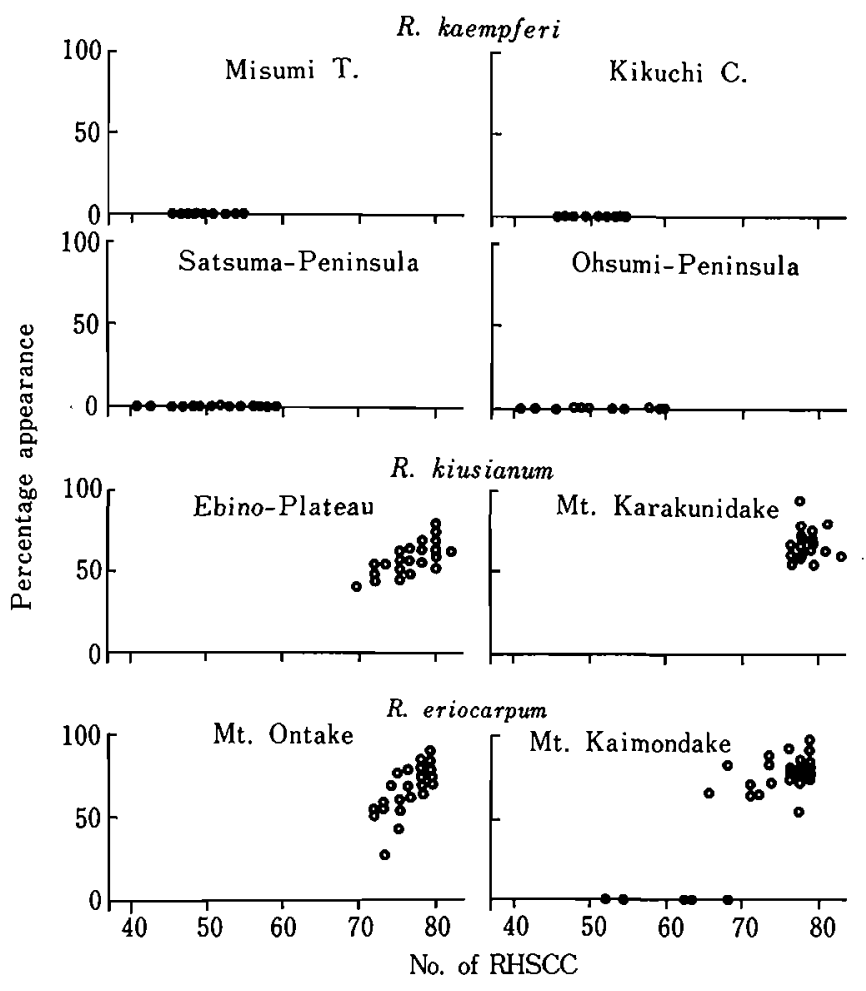

Fig. 5. Frequency distribution of individuals concerning the occurrence of 5-methylated flavonols in $R$. kaempferi, $R$. kiusianum and $R$. eriocarpum.

prominent blotches, variation in both populations was quite narrow. The flowers ranged from 21 to $36 \mathrm{~mm}$ in diameter, and the prominent blotches occurred in less than $10 \%$ of the individuals (Fig. 4). Thus, the small flowers without prominent blotches were thought to be typical characteristics of $R$. kiusianum.

In view of their extremely narrow variations in the phenotypic and pigmental characteristics, and as their habitat in southern Kyushu is restricted to the high volcanic mountains, it seems likely that these populations also represent true forms.

As regard the flower-colour of $R$. eriocarpum, the variation found in the population of Mt. Kaimondake was wider than that found in the population of Mt. Ontake. The former population contained individuals with flower-colour ranging from red through pink to purple, whereas the latter contained those with flower-colour confined to purple or violet (Fig. 3). Analogous situations to the above could be seen concerning petal-pigmentation. As compared with the former population which contained some individuals without the delphinidinseries or 5-methylated flavonols, in all individuals of the latter population, 22 to $70 \%$ of the total anthocyanins were the delphinidin-series, and 5 -methylated flavonols amounted to 28 to $88 \%$ of the total flavonols (Figs. 5 and 6). This may be one of the reasons why the population of $\mathrm{Mt}$. Kaimondake showed wider variation in flower-colour.

Concerning flower-size, individuals in both populations showed considerable intra-populational variations in diameter, ranging from 18 to $53 \mathrm{~mm}$. However, conceming petal-blotch, two populations differed. In nearly $50 \%$ of individuals in the population of Mt. Ontake, the prominent blotches occurred, whereas those occurred in more than $75 \%$ of individuals in the population of Mt. Kaimondake (Fig. 4).

From the viewpoints of the narrow variation in the phenotypic and pigmental characteristics other than flower-size seen in the population of Mt. On- 

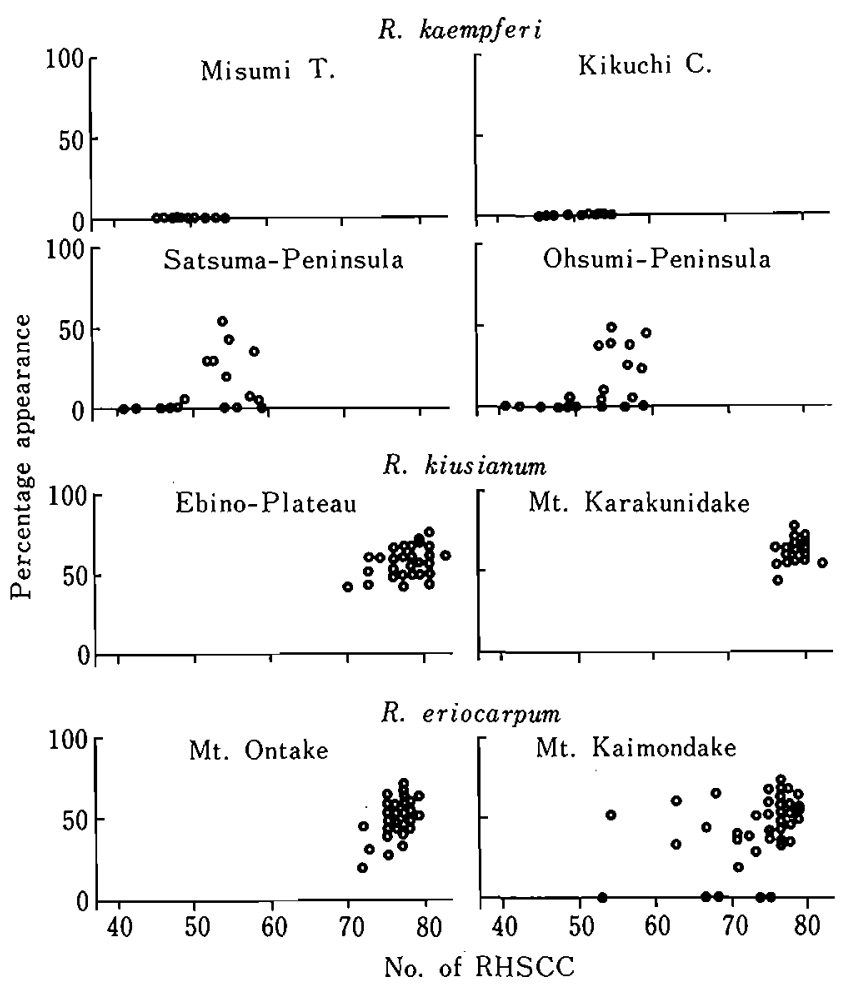

Fig. 6. Frequency distribution of individuals concerning the occurrence of anthocyanins of the delphinidin-series in $R$. kaempferi, $R$. kiusianum and $R$. eriocarpum.

take, and as the habitat in Tokara-Archipelago is restricted to the active volcanic mountains, this population seems likely to be a true species. On the other hand, the wide variation in characteristics in the population of Mt. Kaimondake suggests that it has resulted from further introgressions of $R$. kaempferi to the true $R$. eriocarpum once distributed at the summit, as in the case of $R$. kaempferi in the southern Kyushu.

In any case, the populations of $R$. kaempferi $i$ and $R$. eriocarpum in southern Kyushu exhibited wider variations and contained many peculiar individuals with respect to their floral characteristics. Therefore, we can easily adopt the more promising germplasms as the materials of future breeding among their natural variations.

\section{Acknowledgment}

The authors are greatful to Dr. P.G.Valder of Sydney University for his critical reading of this manuscript.

\section{Literature Cited}

1. Arisumi, K., Y. Sakata and I. Miyajima. 1985. Studies on the flower colours in Rhododendron. I. Pigment constitutions of the elepidote and some lepidote rhododendrons. Mem. Fac. Agr. Kagoshima Univ. 21 : 133-147.

2. Arisumi, K., Y. Sakata and K. Kuwahara. 1986. Studies on the flower colours of rhododendrons in Mt. Kirishima and Mt. Takakuma. Showa 60 Nendo Kagaku Kenkyuhi Hojokin (C-60560038) Kenkyu Hokokusho (Sci. Rep. for financial support of Minist. Educ.) p.1-21. (In Japanese).

3. Kobayashi, Y. 1978. Studies on the flower colour in Rhododendron. I. On the development of greenhouse Belgian azaleas. Bul. Fukuoka Hort. Exp. Sta. $18: 33-40$. (In Japanese).

4. Kunishige, M. 1974. Wagakuni no satsuki engei hinshu (Satsuki azaleas in Japan). Agr. Hort. $49:$ 681-686. (In Japanese).

5. Kunishige, M. and Y. Kobayashi. 1980. Chromatographic identification of Japanese azalea species and hybrids. p.227-287. In : J.L. Luteyn 
and M.E. O'Brien (eds.). Contributions toward a classification of Rhododendron. New York Bot. Garden, New York.

6. Ohwi, J. 1972. Flora of Japan. p.1020-1034. Shibundo, Tokyo.

7. Yamazaki, T. 1976. Tsutsuzi zoku no bunrui (The classification of the genus Rhododendron). p.50-57. In : Tsutsuzi. Seibundoshinkosha, Tokyo. (In Japanese).
8. Yamazaki, T. 1989. Ericaceae. p.122-145. In : Y. Satake, J. Ohwi, S. Kitamura and T. Tominari (eds.). Wild flowers of Japan. Woody plants. II. Heibonsha, Tokyo. (In Japanese).

9. Yokoi, M. 1975. Colour and pigment distribution in the cultivars of sellected ornamental plants, with special reference to their contribution to the ornamental value of plants. Transac. Fac. Hort. Chiba Univ. $14: 1-65$.

\author{
九州南部のヤマツツジ，ミヤマキリシマおよびマルバサツキの形態と \\ 色素分布の変異について \\ 坂田祐介 ${ }^{1} \cdot$ 有隅健一 $^{1} \cdot$ 宮島郁夫 $^{2}$ \\ ${ }^{1}$ 鹿児島大学宸学部 890 鹿児島市郡元 \\ ${ }^{2}$ 九州大学侲学部 812 福岡市東区箱崎
}

\begin{abstract}
摘要
九州南部のヤマツツジ群落には花色が豊富なこと, 花径に小輸から大輪までの愊があることおよびブロッ チの無い花弁を持つ個体があることなど，九州中・北 部の群落に比較して形態にかなりの変異が認められた。 色素分布も，後者はシアニジン系のみに限られるのに 対し，前者はシアニジン系にデルフィニジン系の混在 する個体が数多く見られることなど，変異に富んだ様 相を示した。これらの変巽は，九州南部の群落はヤマ ツツジにデルフィニジン系色素を持つ他の種が浸透交 雑したことによって成立した可能性があることを示唂 している。これに対し，蓩島山系暲国岳周辺のミヤマ キリシマ群落の形㶵と色素分布の様相は変異にきわめ てそしかった。おそらく純粋種としてこの群落を捉え てよいであろう。

一方マルバサツキは，卜カラ列島中之島御岳の群落 で花径とブロッチの出現率を除いた諸形質に咬異は認 められなかったが, 限摩半島開聞岳の群落で花色に変 異が認められた。色素的にも5-メチルフラボノールや デルフィニジン系色素を含まない個体が見られ，この 場合は山頂部にすでに侵入しているヤマツツジがマル バサツキとの交雑に与かり，群落の成立に瓿い影を落 としたと考えられる。

一般に異質の “germplasm”が出会うところでは, 諸 形質の変異は大幅に桩大されるが, 九州南部のヤマツ ツジや開閎岳のマルバサツキがそうであろう.したがっ て将来これらの個体を育種材料として用いる場合には， 本研究で認められた多くの変異の中から，より有用な 個体を抽出することが肝要と思之る。
\end{abstract}

